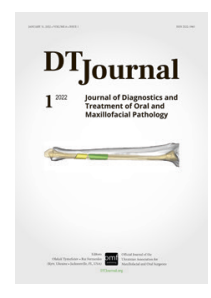

\title{
EDITORIAL
}

\section{Similar Evolutionary Steps: Journal of American College of Surgeons and Journal of Diagnostics and Treatment of Oral and Maxillofacial Pathology}

\author{
levgen I. Fesenko
}

Being online only, we have the opportunity to use electronic/ technical enhancements that will further benefit our readers. ${ }^{1}$ -Timothy J. Eberlein, MD, FACS Editor-in-Chief, JACS

The Journal of American College of Surgeons (JACS) is a highly prestigious monthly peer-reviewed publication devoted to all aspects of surgery. ${ }^{2}$ As of January 28, 2022 the JACS is number 10 among 456 journals in subject area "Medicine" category "Surgery." The 2020 Impact Factor of JACS is $6.113 .^{4}$

The JACS, which has 117 years of traditions of print issues publishing, from January 2022 became a digital-only publication (Table 1 ). ${ }^{1}$ Such transition is another step of the journal evolution in a dynamically changing academic world. Moreover, in one year the JACS implemented two transitions-the change of publisher and movement to digital-only publication. ${ }^{1}$

We recognize five different forms of journal's evolution/transition: (1) language transition (from native to English), ${ }^{5,6}$ (2) title transition (from longer to shorter one, changing journal's scope, etc.), (3) publisher transition, (4) publishing format transition

PhD; Managing Editor, JDTOMP, Kyiv, Ukraine.

Corresponding author's address: OMF Publishing LLC: Journal of Diagnostics and Treatment of Oral and Maxillofacial Pathology. 13-A Simferopolska Street, Kyiv 02096, Ukraine.

E-mail: i.i.fesenko@dtjournal.org (from print-and-online to digital-only), ${ }^{7,8}(5)$ transition from subscription to open access model, etc.

The Journal of Diagnostics and Treatment of Oral and Maxillofacial Pathology (JDTOMP) has also made the publishing format transition from January 1,2022 . Being a digital-only journal, or more correct to say a "printable digital journal," brings a lot of advantages. The wave of such transitions is already growing. Multiple journals and publishers are on that wave. Among them, some journals with a long history of print issues publishing (before transition to digital-only format) like JACS (117 years) and ANZ Journal of Surgery (90 years), ${ }^{8}$ others - with a shorter hisrtory like Global Spine Journal (9 years) ${ }^{7}$ or JDTOMP (5 years).

What is interesting, simultaneously with a publishing format transition, the JDTOMP performed the transition from hybrid publishing model (print issues subscription at the "Presa" State Enterprise and open access via website www. dtjournal.org) to open access-only model. It was a 5 -year period of collaboration with state institution focused on distribution of periodicals and we are
Please cite this article as: Fesenko II. Similar evolutionary steps: Journal of American College of Surgeons and Journal of Diagnostics and Treatment of Oral and Maxillofacial Pathology. J Diagn Treat Oral Maxillofac Pathol 2021;6(1):7-8.

Available online 29 January 2022

https://doi.org/10.23999/j.dtomp.2022.1.4

(c) 2022 OMF Publishing, LLC. This is an open access article under the CC BY license (http://creativecommons.org/licenses/by-nc/4.0/). 
TABLE 1. Comparison of Two Journals That Have Moved to Digital-only Format. 12,2

\begin{tabular}{|c|l|c|c|c|}
\hline \# & \multicolumn{1}{|c|}{ Title } & 2020 Impact Factor & $\begin{array}{c}\text { Number of Years of Print } \\
\text { Format Publishing }\end{array}$ & $\begin{array}{c}\text { Month and Year of Transition to } \\
\text { Digital-only Format }\end{array}$ \\
\hline 1 & $\begin{array}{l}\text { Journal of American College of } \\
\text { Surgeons (formerly known as } \\
\text { Surgery, Gynecology \& Obstetrics } \\
[1905-1994])^{3}\end{array}$ & 6.113 & 117 & January 2022 \\
\hline 2 & $\begin{array}{l}\text { Journal of Diagnostics and } \\
\text { Treatment of Oral and } \\
\text { Maxillofacial Pathology }\end{array}$ & - & 5 & January 2022 \\
\hline
\end{tabular}

grateful for every minute of that way together.

So, we are honored to be with such a famous publication as JACS at the same wave of journals' evolution. On behalf of the Editorial Board we are wishing them and other journals to use this and other advantages of the digital era.

\section{You can't stop the waves, but you can learn to surf.} -John Kabat-Zinn

Professor, Founder of the Mindfulness-Bases stress reduction program

\section{REFERENCES (8)}

1. American College of Surgeons: publications: the Journal of the American College of Surgeons [document on the internet]; 26 Jan 2022 [cited 26 Jan 2022]. Available from:

https://www.facs.org/publications/jacs

2. Scimago journal \& country rank [document on the internet]; 26 Jan 2022 [cited 26 Jan 2022]. Available from:

https://www.scimagojr.com/journalrank. php?category $=2746$

3. The Journal of the American College of Surgeons [document on the internet]; 26 Jan 2022 [cited 26 Jan 2022]. Available from:

https://journals.lww.com/journalacs/pages/default. aspx
4. Bulletin of the American College of Surgeons: news: Journal of the American College of Surgeons is now all-digital [document on the internet]; 5 Jan 2022 [cited 26 Jan 2022]. Available from:

https://bulletin.facs.org/2022/01/journal-of-theamerican-college-of-surgeons-is-now-all-digital/

5. Tymofieiev OO, Fesenko OD, Fesenko II. Transition from Korean to English language of South Korean journals both dedicated to the oral and maxillofacial surgery (OMS): the transitions' impact on OMS residency programs. J Diagn Treat Oral Maxillofac Pathol 2018;2(4):155-64.

https://doi.org/10.23999/j.dtomp.2018.4.3

6. Ganry L, Tymofieiev OO, Kilipiris EG, Zhehulovych ZY, Fesenko OD, Fesenko II. Transition from a French-language to an exclusively English-language journal dedicated to oral and maxillofacial surgery: the transition's impact on journal's growth, internationalization, and academic career. J Diagn Treat Oral Maxillofac Pathol 2019;3(1):9-17.

https://doi.org/10.23999/j.dtomp.2019.1.5

7. Wang JC, Chapman JR, Wiechert K. Moving toward the future: online only. Global Spine Journal 2019;9(5):465.

https://doi.org/10.1177/2192568219852105

8. Tymofieiev OO, Fesenko II, Kilipiris EG. Evolving: becoming a printable digital-only journal from January 2022. J Diagn Treat Oral Maxillofac Pathol 2021;5(12):137-8.

https://doi.org/10.23999/j.dtomp.2021.12.2 